\title{
FORGED CHECKS-THE DUTY OF THE DEPOSITOR TO HIS BANK
}

\author{
Herschel W. Arant \\ Assistant Professor of Law, Yale University
}

During the last twenty-five years the courts with increasing frequency have been called upon to decide where the law ought to place the loss when a bank pays a forged check and charges it to the account of a depositor, believing that he drew the check as presented. The broad statement that a bank pays a check at its peril is so frequently met with that it is likely to make the impression that a depositor enjoys an immunity from change in his legal relations to the bank, save as the bank pays checks. that are in fact his orders. It is well settled, however, that the failure of a depositor to notify his bank after he knows, or ought to know, that it has paid a forged check and charged it to his account, will, under some circumstances, result in undesirable financial consequence to him, though its extent, as well as the basis upon which it is imposed, are matters about which there is a variety of judicial opinion. It is proposed to examine herein the broad principle referred to above and seek to ascertain when and to what extent the depositor's conduct subsequent to payment affects his legal relations to the bank.

In most of the cases that raise the question referred to, there has been a series of forgeries by some dishonest clerk. He may have executed the forgeries so skilfully or he may have so manipulated his employer's books of account that his wrongdoing has extended over a considerable period without detection. Or the forgeries may have been such that a careful examination of the pass-book ${ }^{1}$ or monthly statement and vouchers would have resulted in their detection, but the depositor has either failed to make such an examination or unwittingly confided it to the dishonest clerk. Or, again, the depositor may even have acquired actual knowledge of the forgeries from an examination of his statement and vouchers or otherwise, and yet he may have wilfully or negligently failed promptly to notify the bank of the forgery. In any of these situations, when the depositor demands that the bank pay him his balance, alleging it to include the amounts of the

\footnotetext{
${ }^{1}$ The use of the pass-book, which is referred to in many of the earlier cases, for any purpose other than as a record of deposits is now very generally discontinued. It was once the custom for the depositor to bring in his pass-book whenever he wished a statement of his account. Checks charged to him would then be entered, his balance ascertained and the book, together with the checks so charged, returned. The present practice is to send to the depositor a statement at the end of each month, showing his credits and debits, together with his cancelled checks.
} 
forged checks charged to him, the courts are required to determine what effect, if any, his conduct has upon his right to recover the balance claimed to be due, and this they are generally required to do in the very action in which the depositor demands judgment. ${ }^{2}$ Almost unanimously, in the cases that have arisen so far in this country, the courts have disapproved of the depositor's departure from that standard of conduct usually adhered to by ordinary business men under similar circumstances. $^{3}$ Though the disapproval of the various courts, as shown by the undesirable financial consequence visited upon the remiss depositor, has varied in extent, there has not been as much variety of opinion in this respect as in the theories by which the courts have accounted for their conclusions.

In order that a comparison may be made of the views, in these respects, of the different courts in such cases, suppose a series of forgeries to have been perpetrated and to have extended over several months of time before discovery, the bank having returned regularly each month to the depositor his cancelled checks with a statement of account. Let the problem be considered, first, with reference to checks paid and returned with the first monthly statement received by the

\footnotetext{
2This fact has at times led to the supposition that the bank's claim for the injury caused it by the depositor's failure to give prompt notice must necessarily be adjudicated in the action which the depositor brings to recover his balance. For example, in criticizing the rule laid down in Critten v. Chemical National Bank (1902) 17 I N. Y. 219,63 N. E. 969, it was said: "But such a decision while, perhaps, fair enough in the particular circumstances of this case, might easily lead to awkward results. The direct effect would be to have the Court determining the actual obligations of the parties before it, by the possible obligations of third parties not represented, and liquidating the damages in one action by a claim wholly unliquidated, and, perhaps, never to be enforced or even put forward by another." Chipman, The Pass-Book and Forgery (I908) 28 CAN. L. Times \& REv. 527, 534

This criticism assumes that the bank must use its claim to repel that of the depositor, whereas it is merely privileged to do so. That a separate action may be brought by the bank has been recognized. In Leather Manufacturer's Bank $v$. Morgan (1885) II7 U. S. 96, Ir5, 6 Sup. Ct. 657, 665, it was said: "An inquiry as to the damages in money actually sustained by the bank, by reason of the neglect of the depositor to give notice of the forgeries, might be proper if this were an action by it to recover damages for a violation of his duty." See also the well-known dictum of Cockburn, C. J., in Swan v. North British Australasian Co. (I863, Exch. Ch.) 2 Hurl. \& Colt. I75, I88, which was approved in Guardiass of Halifax Union v. Wheelwright (I875) L. R. Io Exch. I83, 192; Greenfield Savings Bank v. Stowell (1877) I23 Mass. 196, 201; and Mechanics National Bank v. Harter (1899) 63 N. J. L. 578, 582, 44 Atl. 715, 716.

${ }^{3}$ In England, it seems that the depositor may omit to examine his pass-book or. monthly statement with impunity. Walker v. Manchester \& Liverpool District Banking Co (19I3, K. B.) 29 T. L. R. 492. See also Kepitigalla Rubber Estates, Ltd. v. National Bank of India [rgog] $2 \mathrm{~K}$. B. Ioro; Lewes Sanitary Steam Lanndry Co., Ltd. v. Barclay \& Co., Ltd. (I906, K.B.) 95 L. T. R. 444.
} 
depositor after the forgeries began and, secondly, as to checks similarly and subsequently forged."

$I$

The undertaking of the bank is to pay according to the depositor's order to the extent of his balance. When a valid check is presented to the bank for payment, there is created a power in the bank to change its legal relations with its depositor by paying the check. Such payment has as its legal consequence the satisfaction pro tanto of the bank's indebtedness. All the courts agree that, assuming the depositor to have done nothing to lead the bank reasonably to believe that a forged check is genuine and otherwise to have acted prudently, the payment of a forged check does not operate to decrease the bank's indebtedness. ${ }^{5}$ The depositor under such circumstances had done no act intended to result in a power in the bank to decrease its indebtedness nor does justice require that the same legal result should follow as if an act had been done by the depositor for such a purpose. ${ }^{6}$ If nothing else should ever happen, it would be correct to say that "the bank pays at its peril."

But this is usually not the whole story. In the typical case, the bank sends to the depositor a statement of his account with the cancelled checks, assumed by it to have been drawn by him for the purpose of conferring upon it a power, which it claims to have exercised with the result shown by the statement of account. The depositor then omits

\footnotetext{
'To the present writer it seems clear that the bank's claim to credit for payments made under such circumstances rests, with reference to each class of checks, on distinctly different grounds and that each class of payments calls for the application of a different principle. It is often supposed, however, that the basis of the court's conclusion in each class of forgeries is the same. See Chipman, op. cit., supra note 2; Walker v. Manchester \& Liverpool District Banking Co., supra note 3; Lewes Sanitary Steam Laundry Co. Ltd. v. Barclay \& Co. Ltd., supra note 3; Myers v. Southwestern Nationl Bank (1899) I93 Pa. I, 44 Atl. 280; Weinstein v. National Bank of Jefferson (I887) 69 Tex. 38, 6 S. W. I7I; Leather Manufacturer's Bank v. Morgan, supra note 2; First National Bank of Richmond v. Richmond Electric Co. (I907) 106 Va. 347, 56 S. E. 152; Hardy \& Bros. v. Chesapeake Bank (I879) 5I Md. 562; McNeeley Co. v. Bank of North America (rg08) 22I Pa. 588, 70 At1. 89I.

${ }^{5} 2$ Morse, Banks and Banking (5th ed. I917) 97; see Hardy \& Bros. v. Chesapeake Bank, supra note 4, at p. 586. But if the forgery consists in raising a check and the payee actually gets the amount originally called for, the bank is protected to that extent. See National Bank of Commerce v. Tacoma Mill Co. (IgIo, C. C. A. gth) 182 Fed. I. Cf. Shipman v. Bank of the State of New York (189I) I26 N. Y. 3I8, 33I, 27 N. E. 37I, 374.

${ }^{6}$ But where the plaintiff signed checks and left them in his book to be used in his absence and a stranger, who was permitted to write a letter at his desk, stole several checks, flled them out and overdrew the plaintiff's account, it was held, in an action to recover a balance claimed, that the plaintiff must pay the overdraft. Allen Grocery Company v. Bank of Buchanan County (I916) I92 Mo. App. 476, 182 S. W. 777.
} 
to examine the statement or, having examined it and having discovered the forgeries, he fails within a reasonable time to notify the bank that it has erroneously charged checks to his account. But he demands that the bank be required to pay him his balance and that no deduction from his claim be made because of the payment of the forged checks or because of his conduct in the premises, contending that the bank was under a duty to him to pay according to his order, that the credits which it claims are for payments made otherwise, and that he was under no duty to the bank to give notice that such payments were made without authorization. The bank, on the other hand, maintains that his conduct has not been such as was to be expected of a reasonably prudent man under the circumstances and that it was his duty so to conduct himself in the premises as to give to it the largest possible chance to retrieve the loss incident to an innocent error. Under these circumstances, the depositor's conduct meets with the approval of no American court. While unanimously admitting that the facts which have happened up to the time when the bank charges the forged check to the depositor's account do not alone suffice to cause those changes of legal relation, which we may shortly characterize as a pro tanto decrease of the bank's indebtedness, all the courts in this country agree that when the depositor acquires, or is chargeable with, knowledge of those facts, there results, as a legal consequence, a new relation, which the courts say is a "duty" to notify the bank promptly. Some courts view this so-called duty of the depositor to give notice quite apart from his other relations to the bank and have no difficulty in reaching the conclusion that he is charged with, or must pay, such a sum as will recompense the bank for whatever injury it has sustained as the proximate result of his failure to give notice and the bank is allowed an offset against the depositor's claim to the extent of the losses so resulting to the bank. Others, to whom the well-known doctrines of ratification, adoption, and estoppel are suggested, apply one of these terms to the depositor's conduct and, with its mere name, they conjure the conclusion that the indebtedness of the bank has been reduced to the extent of the forged checks paid.

Before discussing these varying views of the courts, it is worth while to notice some of the language which they have used in the leading cases.

The Supreme Court of Alabama in the case of First National Bank $v$. Allen, ${ }^{7}$ a suit by a depositor against the bank to recover an amount equal to a series of forged checks charged to the plaintiff, said, with reference to the class of checks which we are now considering:

"The depositor owed the bank a duty which was to examine the pass book and vouchers with reasonable care and diligence. If the deposi-

\footnotetext{
' (1893) 100 Ala. 476, 485, I4 So. $335,337$.
} 
tor failed in his duty in this respect, and the bank was injured in consequence of such omission of duty, the depositor becomes liable to the bank for all such damages. The extent of the liability of the depositor is commensurate with the loss sustained in consequence of his neglect of duty; no more, no less. It would be unjust, unfair to the depositor, not sanctioned by any correct principle of law, to permit the bank to invoke the doctrine of ratification or estoppel, which would exempt the bank from all liability incurred by its own neglect in the payment of the forged check, and in many cases inflict on the depositor a greater loss than that caused to the bank by his neglect of duty. The damages sustained by the bank as a result of neglect of duty by the depositor are as susceptible of proof and measurement as arise in any other case of breach of duty imposed by contract."

The Supreme Court of New York in a later case, ${ }^{8}$ involving a pre- . cisely similar situation, approved the reasoning of the Alabama Court, saying:

"We see no reason why the bank should be entitled to anything more than indemnity for the loss the depositor's negligence has caused it."

In De Feriet v. Bank of America, a depositor sought to recover a balance alleged to be due him. It appeared that a $\$ 2,500$ check had been forged and paid by the bank and that the depositor had learned of the facts but had given the bank no notice. Six months later a similarly forged check for $\$ I, 700$ was paid, which overdrew the plaintiff's account $\$ 1,774.59$. The plaintiff's suit was based on the assumption that the bank was entitled to no credit for payment of either check. The bank denied any indebtedness whatever to the depositor and claimed judgment for the amount of the overdraft. The court held that the bank was entitled to judgment, saying, with reference to the first forged check:

"Under these circumstances, it is clear that the plaintiff cannot be heard to disavow the check for $\$ 2,500$. . . . . So far as was in his power he condoned this offense of his bookkeeper, and made the transaction his own."

The Supreme Court of Massachusetts had the same question presented for decision in the case of Dana v. National Bank of the Republic, ${ }^{10}$ an action by a depositor against a bank to recover a balance, where a clerk had fraudulently erased the name of the payee of a check drawn by the plaintiff, made it payable to bearer and himself received payment from the bank on November 20, I874. The bank returned this check with a statement of account on the first of December following, and the

${ }^{8}$ Critten v. Chemical National Bank (I902) I7r N. Y. 219, 229, 63 N. E. 969, 972. See approving note (Ig02) 2 CoL. L. REv. 490.

- (I87r) 23 La. Ann. 3Io, 3rr.

${ }^{10}$ (I882) I32 Mass. I56, I59. 
balance shown by a statement rendered the first of the following January was drawn out during that month and the account closed. The plaintiff gave no notice of the forgery until twenty-three months after the check was paid. The dishonest clerk had been entrusted with the examination of the statement of account and vouchers. The court said :

"If the plaintiffs knew of the mistake, or if they had that notice of it which consists in facts which, by the exercise of due care and diligence will disclose it, they failed in their duty; and adoption of the check and ratification of the payment will be implied. They cannot now require the defendant to correct a mistake to its injury, from which it might have protected itself but for the negligence of the plaintiff."11

In H.ardy \& Bros. v. Chesapeake Bank,,$^{12}$ an action brought to recover a balance alleged to be due, a clerk had forged fourteen checks before his wrongdoing was discovered. The first five of these checks were returned with the statement on July I3, 1873 , and the others on October sixth following. The forgeries were discovered October tenth. The bank admitted its liability for the five checks first returned. The court referring to these checks said:

"If the acts and knowledge of the agent in making the entries of those checks in the bank book could be properly imputed to the appellants, irrespective of knowledge in fact, those entries would amount to a ratification and adoption of the acts of Holmes in drawing those checks, as well as those dated subsequent to the I 3 th day of July, I873." ${ }^{\prime 3}$

\footnotetext{
"The legal effect of the implied "adoption of the check," if it has any, seems to be the same as if the depositor had himself authorized the signing of it to begin with. If so, this is what is usually meant by ratifying the check and it is unnecessary to infer any ratification of the payment. Indeed, it is difficult to see how payment could be ratified for the bank is the debtor of the depositor. It is not his agent in fact and does not profess to be such, but at least one writer based a criticism of the doctrine of Critten $v$. Chemical National Bank, supra note 2 , in large part on the theory that the relation was one of agency. See Chipman, op. cit. 534 .

12 (1879) 51 Md. 562, 569.

${ }^{13}$ Quite generally the courts, in this class of cases, use the terms "ratification" and "adoption," as here, to mean the same thing. If the depositor can, when the check has been forged and paid, by his own act cause a change of legal relation, . i. e., make the consequence the same as it would have been had the check paid been genuine, his exercise of this power is what is usually called ratification. In Hefner v. Vandolah (1872) 62 I11. 483,485 , it was said that the court was justified in finding that the defendant had understandingly "adopted and ratified the use of his name and that there was no difference between an "adoption and ratifica"tion" of this kind and the case where the person whose name had been forged had, in the first instance, authorized the forger to sign it. The court's statement that knowledge of the appellants, at a given time, that their names had been forged would amount to a "ratification and adoption" of the subsequent drawing of checks is a most unusual use of these terms.
} 
In Leather Manufacturer's Bank v. Morgan, ${ }^{14}$ a clerk had perpetrated a series of forgeries extending from September II, I880, to February 14, I88r. Fourteen checks, drawn by the clerk and signed by the plaintiff, had been altered. The amount of each was raised and where the check was not, according to its original tenor, payable to bearer, it was altered so that it became so payable. The plaintiff's pass-book was written up and returned on October 7,1880 , with his cancelled checks, among which were the first two checks raised by the clerk, these checks being payable to "cash or bearer." The second time the pass-book was balanced two other checks similarly altered were returned and also three checks where the words, "or bearer," were written after the payee's name. The clerk absconded, and the plaintiff, on March second, I88I, had his pass-book balanced. Two checks were returned this time which had been raised and made payable to bearer. The plaintiff immediately discovered the forgeries and gave notice to the bank. In a suit to recover his balance, which he alleged to include the amounts that had been paid by the bank on the forged checks, the Supreme Court of the United States, reversing the lower court, which had held that the depositor was under no duty to examine his pass-book and vouchers, said :

"If he had discovered that altered checks were embraced in the account, and failed to give due notice thereof to the bank, it could not be doubted that he would have been estopped to dispute the genuineness of the checks in the form in which they were paid. ... . Still further, if the depositor was guilty of negligence in not discovering and giving notice of the fraud of his clerk, then the bank was thereby prejudiced, because it was prevented from taking steps, by the arrest of the criminal, or by an attachment of his property, or other form of proceeding, to compel restitution. It is not necessary that it should be made to appear, by evidence, that benefit would certainly have accrued to the Bank from an attempt to secure payment from the criminal. Whether the depositor is to be held as having ratified what his clerk did, or to have adopted the checks paid by the bank $k^{15}$ and charged to him, cannot be made, in this action, to depend upon a calculation whether the criminal had at the time the forgeries were committed, or subsequently; property sufficient to meet the demands of the Bank. An inquiry as to the damages in money actually sustained by the Bank, by reason of the neglect of the depositor to give notice of the forgeries, might be proper if there were an action by it to recover damages for a violation of his duty. But it is a suit by the depositor, in effect, to falsify a stated account, to the injury of the bank, whose defense is that the depositor has, by his conduct, ratified or adopted the payment of the altered checks, and thereby induced it to forbear taking steps for its protection against the person committing the forgeries. ${ }^{16}$ As the right to seek

\footnotetext{
14 (I885) II7 U. S. 96, II3, 6 Sup. Ct. 657, 663.

${ }^{25}$ See supra note Ir.

${ }^{28}$ It is usually held that if one "ratifies" or "adopts" he is bound. Reliance by the other party upon his acts is not necessary. If it was, the so-called ratifier
} 
and compel restoration and payment from the person committing the forgeries was, in itself, a valuable one, it is sufficient if it appears that the Bank, by reason of the negligence of the depositor, was prevented ${ }^{17}$ from promptly and, it may be, effectively exercising it."18

In the case of Janin v. London \& San Francisco Bank, ${ }^{19}$ the plaintiff's name was forged to a check for $\$ 16,700$ which was paid by the bank on May twenty-ninth, I878, and returned with a statement of account on September fourth. Another statement was rendered December eleventh; and on the twenty-eighth the plaintiff intimated a doubt as to the genuineness of the check, but made no claim that it was a forgery until February first, I879. In an action to recover his balance, including the amount charged to him for the payment of this check, the bank set up as a defence that the "plaintiff was estopped to deny the genuineness of the check, because of his negligence in not examining his balanced passbook and returned vouchers, including the one in dispute, within a reasonable time and giving notice that such check was forged, by reason of which laches the defendant was prevented from tracing out the forger of said check or said signature, if it was a forgery, and proceeding against him for a period of nearly five months and until all trace of said forger was lost." The Supreme Court of California, sustaining a recovery by the plaintiff, said:

"The plaintiff was in no manner responsible for the action of the defendant in paying the check. In making such payment it parted with its own money, and not that of the plaintiff; and the loss consequent thereon was its own, and should not be transferred to the plaintiff, unless, from all the circumstances in the case, it appears reasonably probable that, but for his alleged negligence, the defendant could have protected itself. The defendant has not in fact discharged its indebtedness to plaintiff, and should not be permitted to debit him with any amount as an offset thereto unless it appears that by reason of the negligent conduct of the plaintiff it has omitted to take proceedings which it otherwise would and could have taken to indemnify itself from loss. This seems to us clear upon the plainest principles of justice. The balancing of the pass-book in September, and charging the plaintiff therein with the amount of the check, and its return to him at the same time, constituted a statement of account between himself and the defendant, and it thereupon became the duty of the plaintiff to examine the same within a reasonable time, and give to defendant, without unreasonable delay, notice of any objection which he had to it; and unless such objection was made within a reasonable time it became an account stated, and there was imposed upon the plaintiff the burden of showing

would have no power to make the bank's payment of the forged check tantamount to payment of a genuine check.

${ }^{27}$ This does not mean that the depositor has in any way obstructed procedure by the bank, but that he has simply failed to inform the bank that it had a cause of action.

${ }^{18}$ Italics are the present writer's.

${ }^{10}$ (189r) 92 Calif. I4, 23, 27 Pac. Iroo, Iror. • 
that the check with which he was debited was a forgery; and in addition to this, if the circumstances attending the entire transaction were such as to make it reasonably probable that the bank had suffered prejudice by plaintiff's unreasonable acquiescence in the account stated, he would not be permitted to open the account by proof of its incorrectness."

In similar vein, Professor Williston says : ${ }^{20}$

"Other circumstances besides the purchase of the forged instrument on the faith of a representation may afford ground for an estoppel. Thus, where a customer of a bank has negligently failed for a long period to examine cancelled checks and discover a forgery, as he would have by such examination, he is estopped afterwards to assert his claim against the bank which has been deprived of the means to protect itself by recovery against another."

It is said by the Supreme Court of Michigan that the failure to object to improper charges is to acquiesce in the amount as stated and places on the depositor the burden of proving the incorrectness of the charge. ${ }^{21}$

The foregoing quotations make it clear that the common statement that a "bank pays at its peril" cannot safely be used as a basis to prophesy courts' actions under all circumstances. By the majority view, assuming that the depositor has been negligent in giving notice of the forgery, the bank need not. pay him such amounts as were charged to him on account of the forged checks paid; and most of the courts which hold this view do not require that a causal relation be established between the depositor's dereliction and a loss to the bank equal in amount to the forged checks paid. It suffices if the bank shows any loss to have resulted.

The different theories by which this conclusion has been reached will be separately considered.

\section{RATIFICATION}

Concerning the question whether one can ratify his forged signature, Professor Williston says :22

"Whether a forgery can subsequently be ratified or adopted without estoppel or new consideration is a question to which judicial answers are hopelessly conflicting. It is pointed out that since the forgery did not purport to be made on behalf of the person whose name was forged, there can be no ratification. This criticism is sound. The person whose signature it is may indeed adopt it, but adoption involves no fictitious relation and to sustain a recovery after adoption either consideration or estoppel should be requisite. Called by whatever name the doctrine may be, the vital question is whether the enforcement of the instrument without this basis should be permitted."

${ }^{20} 2$ Contracts ( 1920$) 2 \mathrm{I} 24$.

${ }^{21}$ American National Banik v. Bushey (188I) 45 Mich. I35, 7 N. W. 725.

${ }^{22}$ Op. cit. 2123 . 
It seems to be entirely agreed that an unauthorized act in order to be capable of ratification by one must in fact be done by another as his agent. ${ }^{23}$ There is disagreement, however, upon the question whether there must also be a profession of agency. The more widely prevailing view holds such profession to be indispensable. ${ }^{24}$ But a few courts have held that one who has full knowledge of the facts can ratify his forged signature. ${ }^{25}$ Assuming such knowledge, one's sense of justice receives no shock when the law makes the legal consequence of the ratifier's act exactly what he intended it to be, and, unless such consequence operates substantially to the detriment of the social welfare, it seems entirely unobjectionable. ${ }^{26}$ The reason generally given for the view that a forgery cannot be ratified is that to permit such would encourage the compromise of crime. The Supreme Court of Indiana, voicing the more prevalent view, said that "it is impossible in such a case to attribute any motive to the ratifying party but that of concealing the crime and suppressing the prosecution." ${ }^{\text {, }}$ But in a case where a maker of a

${ }^{2}$ I Mechem, Agency (rgr4) sec. 386 et seq.

${ }^{24}$ I Mechem, op. cit. 28i-282. See 36 L. R. A. (N. s.) roo6, note. But the representation of authority may be implied from conduct alone. Scott v. Bank of New Brunswick (1894) 23 Can. Sup. Ct. 277, 281.

${ }^{25}$ Greenfield Bank v. Crafts (1862, Mass.) 4.Allen, 447; Cravens v. Gillilan (I876) 63 Mo. 28; Fay v. Slanghter (I902) I94 Ill. I57,62 N. E. 592; Campbell v. Campbell (Igor) I33 Calif. 33, 65 Pac. I34; Montgomery v. Crossthwait (1890) 90 Ala. 553, 8 So. 498 . See M'Kenzie v. British Linen Co. (I881, H. L.) L. R. 6 A. C. 82,99 ; Scott $v$. Bank of New Brunswick, supra note 24 . It seems to be immaterial that the drawee bank had no knowledge of the forgery. De Feriet $v$. Bank of America, supra note 9.

Of course the forger may" be punished criminally notwithstanding the ratification. Hozvell v. McCrie (1887) $36 \mathrm{Kan} .636$, I4 Pac. 257. In M'Kenzie v. British Linen Co., supra note 25, Lord Blackburn, at p. 99, said: "I wish to guard against being supposed to say that if a document with an unauthorized signature was uttered under such circumstances of intent to defraud that it amounted to the crime of forgery, it is in the power of the person whose namo was forged to ratify it so as to make a defence for the forger against a criminal charge. I do not think he could. But if the person whose name was without authority used chooses to ratify the act, even though known to be a crime, he makes himself civilly responsible just as if he had originally authorized it. It is quite immaterial whether this ratification was made to the person who seeks to avail himself of it or to another."

${ }^{2}$ Heirry v. Heeb (I887) II4 Ind. 275, 280, I6 N. E. 606, 608. In an English case, where there was an agreement not to prosecute, it was held that the forgery could not be ratified for the additional reason that the forged signature was illegal and void, Kelly, C. B., saying that "although a voidable act may be ratified by matter subsequent, it is otherwise when an act is originally and in its inception void." Brook v. Hook (187I) L. R. 6 Exch. 89, 99. To say that the forger's act was void does not aid in answering the question whether there is a power to ratify, because it merely states as a reason for a conclusion the conclusion itself. If the forger's act was void, it was without legal consequence. But certainly it has made him criminally liable and civilly responsible to the person who advanced 
note, knowing his signature to be forged, promised to pay it, the Massachusetts Supreme Court held that he must pay and said that "this must stand on the general principles applicable to other contracts, and is to be defeated only where the agreement was upon the under-

money and, though his act may have imposed no duty on the person whose name was forged, it does not necessarily follow that such person does not acquire a power to ratify. Society can and should make this a consequence if it is, on the whole, socially desirable; if it does not see fit to make it a consequence, then there is no power to ratify, but it does not aid to this conclusion to say that the forger's act was "originally and in its inception void." See also x Mechem, op. cit. 265.

In Scott v. Bank of New Brunswick, supra note 24, where the plaintiff's indorsement had been forged upon a non-negotiable certificate of deposit, which had been surrendered for value to the defendant, referring to the above language of Baron Kelly, it is said at p. 285 :

"This last ratio decidendi is clearly inconsistent with Lord Blackburn's enunciation of the law in McKenzie v. The British Linen Co., 6 App. Cas. 99, and can no longer be regarded as authority. Moreover the reasoning on which it proceeds would be inapplicable here, for granting that the payment of the money for which the receipt in the present case was given was obtained by Robinson by false and fraudulent pretenses, and that any agreement so brought about would be illegal and void, there would still remain the fact that the money was actually paid over to him by the bank, and it is to this payment that the respondents seek to have the ratification' applied. A contract, or a pretended contract, like a forged note, may be void in law $a b$ initio or nonexistent so that there is nothing to ratify, but a fact like a payment cannot be got rid of in that way. The payment was therefore clearly a substantial act susceptible of ratification. . ..."

It is respectfully submitted that the distinction here suggested is unfounded. If "a contract or pretended contract, like a forged note," is supported by such consideration as would make it enforceable by the promisee or holder, under ordinary circumstances, there is always the very real act of the forger as well as the fact of payment or parting with value; and only the former can be ratified, because the payment by the bank in the check cases is made as debtor and in no case is it made as agent. Fundamentally it makes no difference whether the crook induces the bank to part with value by forging an indorsement on a certificate of deposit, a depositor's signature to a check, or a maker's name to a promissory note. In each case, the ratifier's act is simply added to an already existing aggregate of facts and, when added, is said to have the same legal effect as would have been caused by that aggregate had it included authorization. In each case the question is whether it is socially desirable to make such the consequence of the ratification. It would never be so unless in the preceding aggregate there was a payment or giving of consideration.

In another case where it was claimed that the defendant had ratified his forged signature as maker of a promissory note by promising to pay it, it was said that the plaintiff could not recover because the defendant's promise was without consideration. Workman v. Wright (1878) 33 Ohio St. 305 . No other case has been found which holds consideration necessary to a binding ratification. But if the promisee gave value when such a note was delivered, he at once acquired a quasicontractual cause of action against the forger and, if it was expressed or reasonably to be implied that the promisee relinquished this cause of action or even agreed to forbear to sue upon it in return for the ratifier's promise to pay, there would be ample consideration. The same court in another similar case said:

"Forgery being a crime, there could be no ratification of that crime that could operate to change its character. The crime being completed, it would forever 
standing that, if the signature was adopted, the guilty party was not to be prosecuted for the criminal offense." 28 Should the mere absence of an agreement not to prosecute the forger make this difference, if the probability that there will be no prosecution is substantially as great? One may well doubt with the Indiana court whether the principal desire or expectation of a ratifier is ever any other result. The normal aversion to initiating and sponsoring such prosecutions would generally make the forger safe if the person upon whom he imposed has been satisfied and the failure of such person to initiate criminal proceedings subjects him to no punishment. But the argument of the Indiana court proves too much. If the voluntary promise to pay of the person whose name has been forged is held to be unenforceable because to hold it otherwise would remove the incentive to prosecute, why will the forger himself be required to pay the promissory note which he has given for the money obtained by the forgery ${ }^{29}$ If the third person, instead of ratifying by promising to pay the forged note,

remain a criminal act, and George $M$. Shinew could not by any subsequent conduct or omission on his part ratify a crime that would give validity to an instrument that was absolutely void at the time of its execution. It is true, however, that, while he might not by any act or conduct on his part ratify a forgery of his name, so as to make the instrument a valid instrument, yet he might by his conduct, or even by mere silence, estop himself from defending against the payment of the sanne, on the ground that his signature was a forgery; but before he can be estopped by mere silence facts must be alleged and proven showing a duty and opportunity to speak, that the party to be estopped knew, or had reason to believe, that the holder of the note would rely on his silence, and that he did rely on his silence and was injured thereby." Shinew v. First National Bank (IgrI) 84 Ohio St. 297, 306, 95 N. E. 88I, 882. (Italics are the present writer's.)

The difference between denying Shinew the power by ratification to "make the instrument a valid instrument," i. e., to impose upon himself a duty to pay it, and allowing him to "estop himself from defending against the payment of the same" seems most unsubstantial. In each case his conduct is simply added to the facts which have already happened. How his having to pay under the latter rather than the former theory militates any differently against the public interest is not apparent. He exercises a power in each case, as a practical matter, because the person on whom the forger has imposed will almost necessarily rely upon the defendant's silence and sustain injury as a result of his necessary delay in the prosecution of his remedy against the forger, and this, according to many cases, is sufficient injury. See Leather Manufacturer's Bank v. Morgan, supra note I4. It is well settled that a tort may be ratified. I Mechem, op. cit. secs. 357, 506. And if one should commit a tort, while acting for another but without the scope of his employment, the mere fact that the act done is a crime is not necessarily a reason for denying the power to ratify the tort which usually exists.

${ }^{23}$ Greenfield Bank $v$. Crafts (1862, Mass.) 4 Allen, 447, 455. And where one acknowledged to, a holder of a promissory note that his forged signature as maker was genuine, such acknowledgment was held to be a ratification notwithstanding the fact that the plaintiff was negligent in taking the note. Central National Bank v. Copp (1903) I84 Mass. 328, 68 N. E. 334.

${ }^{2}$ See Chandler v. Johnson (1869) 39 Ga. 85. Cf. Fountain v. Bigham (I912) $235 \mathrm{~Pa} .35,85$ Atl. I3I. Where a postmaster had misappropriated funds and the sureties on his bond demanded a promissory note signed by himself and satis- 
has actually paid it, or if the forger has returned the money received, it can hardly be doubted that it would be held, even if there was a promise not to prosecute, that the cause of action against the forger of the person originally defrauded would be extinguished, ${ }^{30}$ and yet there results the same discouragement to prosecution which follows where there is simply a promise to pay. So long as the prosecution of the forger is not considered vital enough to society's welfare to require, under pain of punishment, that the defrauded person, or any one who knows of the forgery, ${ }^{31}$ take steps looking to the punishment of the criminal it seems reasonable to allow the defrauded person to take steps to make himself whole, by getting either payment or a promise of payment from the payee or from the person whose name was forged, provided he makes no promise not to prosecute. In attempting thus to save himself from loss by another's wrongful act he but follows his human instinct to preserve his own property and he thus keeps within reasonable bounds. In such a situation, there is no substantial public interest that can effectively and consistently be protected or that ought to be protected at what will often prove to be such great cost to the defrauded person. The forger or his friends, among whom will often be the person whose name has been forged, will usually be ready to pay or promise to pay; and, if the defrauded person is unwilling to accept or unsafe in accepting the promise to pay, the money itself will usually be found and there will inevitably be the resulting inclination not to prosecute, simply because human nature is as it is. If the payment extinguishes the forger's debt but the promise creates no duty, the practical result is that a forger can be reasonably certain of not being prosecuted if he is able to get the money with which to pay. If he is not so fortunate, simply because a promise to pay is ineffective, he is at a very practical disadvantage. This would certainly cause no concern if all forgers were in the same predicament. But the case of the

factory sureties to secure them from loss, there being no express agreement by the sureties not to prosecute, it was said that the note and a trust deed to secure it were valid and it was held that equity would not decree the cancellation of the note and deed. Rock v. Mathews (189I) 35 W. Va. 537, I4 S. E. I37.

${ }^{30}$ It is not surprising that no case has been found where it is sought to compel a second payment on the ground that the voluntary receipt of the first was under such circumstances that public policy requires that it be of no effect.

${ }^{x}$ No reason is apparent for holding the defrauded person to a greater duty to see criminal proceedings begun than any other person who has the same information. Neither is penalized if he merely fails to act; and no promise to either, made in consideration of his forbearing or promising to forbear to act, is enforceable. Either is liable criminally at common law if, for a consideration, he desists from, or promises to desist from, prosecuting. Regina v. Burgess (1885) L. R. I6 Q. B. Div. I4I. See contra State v. Jefferson (I9I6) 88 N. J. L. 447,97 Atl. I62. This is the almost universal view under modern statutes. Watt $v$. State (I892) 97 Ala. 72, Ir So. 90I ; People v. Bryon (1894) I03 Calif. 675, 37 Pac. 754; Frilby v. State (1884) 42 Ohio St. 205; State v. Ash (1898) 33 Or. 86, 54 Pac. I84. 
innocent person defrauded, to whom an enforceable promise to pay the debt due him cannot be made and who on this account will very probably lose his money, has both his innocence and his having given value to distinguish it. It seems extremely questionable whether the inconsiderable promotion of society's welfare to be found in the slight increase in probability that the forger will be prosecuted justifies the retention, at such comparably great expense to the defrauded person, of a rule that operates thus inconsistently. On the whole, it seems socially desirable that there should be a power to ratify a forgery of one's signature within the limits named by the Massachusetts court.

But whether one can ratify a forgery of his signature when he has full knowledge of the facts and desires to do so is very different from the instant problem in which there is no intent or desire to ratify and generally nothing more than a constructive knowledge of the acts that are said to be ratified. It is to be noted that there is not here the basis for implying a ratification that exists where one knowingly retains benefits resulting from acts done by another on his behalf. If ratification is to be implied, it is not because of the receipt of benefits but because of the depositor's failure to act for the purpose of preventing loss to the bank..$^{32}$ That this is an anomalous basis for the implication of a ratification cannot be denied; but the application of the doctrine is not to be condemned solely on this account if it works out a result that commends itself as just. It certainly has not the tendency referred to by the Indiana court to discourage prosecution of the forger. The incentive to bring about his punishment is still present; it is merely shifted from the bank to the depositor. But, if the forger has not succeeded in making his escape-the contrary is perhaps more often the case-and is prosecuted and punished, the depositor receives no financial benefit. Can he sue the forger in a civil action? It is well settled that the bank can sue the forger as soon as it has paid money to him..$^{33}$ If the failure of the depositor to give notice is a ratification, the result is a novation. ${ }^{34}$ The depositor is now the creditor of the

s If the bank is negligent in paying the check, it seems that the depositor's silence is not a ratification. Dana v. National Bank of the Republic (I882) I32 Mass. 156, 158. This exception has been said to be "somewhat inconsistent with the principle on which the doctrine rests." Critten v. Chemical National Bank (I902) I7I N. Y. 2I9, 229, 63 N. E. 969, 972. It shows, however, the unwillingness of the court to allow conventionality of application to force it to do an obvious injustice. One wonders if discovery of the forgery by the bank after a payment without negligence would prevent the depositor's silence from being a ratification.

${ }^{3}$ Dudley \& West Bromwich Banking Co.v. Spittle (1860, Ch.) I John. \& Hem. I4. See Leather Manufacturer's Bank v. Morgan, supra note I4.

"Professor Williston, with reference to contracts made by promoters on behalf of corporations not yet organized, says: "The cases generally speak of the obligation of the corporation as created by adoption, but novation seems the 
forger, the bank's cause of action against the forger is extinguished, and its indebtedness to the depositor pro tanto reduced, and this is the consequence notwithstanding the fact that neither the depositor, the bank, nor the forger has assented to such a change in their relations and such consequence might be contrary to the desire of every person concerned if he knew the facts. Justice between the bank and its depositor is thought to require this unusual result, and it is made to follow without any inquiry as to whether the bank would have been in any better position if the depositor had given prompt notice of the forgery as soon as he knew or should have known of it. Since the depositor does not intend or desire to ratify and has received no benefit, justice requires that he be not held to have ratified by failing to give notice of the forgery unless there is a resulting injury to the bank and, even then, only to the extent to which the bank has been injured. The doctrine of ratification, however, has never been applied with such limitations and to so limit it, it is admitted, would be to apply it in a most unusual fashion. Even the unconventional application of the doctrine now made by the courts is but a clumsy and unreliable device for reaching justice and it seems better not to depart from the orthodox basis for its application, in order to improve it, unless the application of no other principle produces a more just result.

ESTOPPEL

It may be observed to begin with that the courts have never held, as suggested by Professor Williston, ${ }^{35}$ that an estoppel is requisite, after adoption, in order to bind the depositor. Whenever the basis for an estoppel was thought to exist, it, without more, was regarded as amply sufficient ground upon which to deny the depositor any recovery. And

more accurate term. If the assent of the corporation to the bargain is merely an adoption of it, the promoter apparently must still remain liable. But it seems more nearly to correspond with the intention of the parties to suppose that when the corporation assents to the contract, it assents to take the place of the promoter-a change of parties to which the other side of the contract assented in advance. There would then be a novation which would discharge the promoter at the time the corporation assumed the obligation." I Contracts, 582.

So where a forged check is paid and the depositor, with knowledge of all the facts, assents that the legal consequence shall be the same as if the check had been genuine, there is no objection in legal theory to the novation consequence, if it is justifiable to imply a consent in advance by the bank that its claim against the forger be transferred to the depositor in return for a pro tanto decrease of its indebtedness to him. But it must be noted that this assumes an intent by the bank with reference to a cause of action when it is ignorant of its existence and must of course be a pure fiction. The result, however, may not be seriously objectionable, since it includes that which was expected by the bank at the time it made payment, as well as that desired by the depositor. The same cannot be said where the depositor simply has constructive knowledge because of his negligence.

${ }^{\text {ss }}$ See supra note 22. 
it seems entirely pertinent to inquire in the beginning why it is necessary to invoke the doctrine of estoppel, a far greater favorite among the courts than either ratification or adoption. Every court which applies it takes as its starting point the so-called duty of the depositor to speak or, otherwise stated, the duty to prevent such loss to the bank as can be prevented only by a prompt disclosure ${ }^{36}$ of such material facts as are known or would be known if a reasonable examination ${ }^{37}$ were

\footnotetext{
${ }^{36}$ In the following cases the depositor was held not to have acted sufficiently promptly. Knights of Joseph Bldg. \& Loan Assoc. v. Guarantee Trust \& Safe Deposit Co. (IgI8) $69 \mathrm{~Pa}$. Super. Ct. 89 (five weeks); Hammerschlag Mfg. Co. v. Importers' \& Traders Nat. Bank (IgI9, C. C. A. 2d) 262 Fed. 266 (nine months); Connors v. Old Forge Discount \& Deposit Bank (19r4) $245 \mathrm{~Pa} .97$, 9r At1. 210 (43 days); McNeeley v. Bank of North America (I908) 22r Pa. 588, 70 Atl. 89I (three and one-half months); Isreal v. State Bank of New Orlears (I909) I24 La. 885, 50 So. 783 (two months). In De Feriet v. Bank of America (187I) 23 La. Ann. 3ro, failure to object for seven days after knowledge of a forgery was held to be a ratification. But notice was held to have been given within a reasonable time where the statement was rendered February 2d, I9I\%, and the forgery discovered by a new clerk on February 20th, the plaintiff being absent from his home at the time the account was rendered and until the thirteenth, when the forging clerk absconded. Denbigh v. First National Bank (Igr8) I02 Wash. 546, I74 Pac. 475. Where notice is given on the day the forgery is discovered, the bank has no claim though the forged check is not tendered until twenty-four days thereafter. Brixen v. Deseret National Bank (I888) 5 Utah, 504, I8 Pac. 43. But if the depositor fails to give notice of forgeries on the day he receives his statement, he is not estopped to deny the genuineness of checks paid on that day. Isreal $v$. State Bank of New Orlears, supra.

Where there is no dispute as to the time of the rendition of the account, and the time of making the objection, the reasonableness of the time in which the depositor should make his objection is a question of law. McKeen v. The Boatmen's Bank (1898) 74 Mo. App. 28I, 289.

${ }^{27}$ The depositor is under no duty so to conduct the examination that it will necessarily lead to the discovery of the fraud. If he examines the voucher personally and is himself deceived by the skilful character of the forgery, his omission to discover it will not shift to him the loss which, in the first instance, is the loss of the bank. National Dredging Co. v. Farmers' Bank (1908, Del.) 6 Pen. 580, 69 Atl. 607. See also Leather Manufacturer's Bank v. Morgan (1885) II7 U. S. 96, 6 Sup. Ct. 657; Hardy v. Chesapeake Bank (I879) 5 I Md. 562. But where the forging clerk had allowed only genuine checks to reach the depositor's hands, a mere comparison of these with the stubs in the check book was not a reasonable examination. The comparison should have included the check list. Morgan $v$. United States Mortgage \& Trust Co. (1913) 208 N. Y. 2x8, тот N. E. 87r. See also First National Bank v. Richmond Electric Co. (1907) I06 Va. 347, 56 S. E. I52. The depositor was also charged with notice of a forgery where he saw a check filled out in a strange handwriting for which there was no corresponding stub, though his signature thereon was so skilfully forged as to defy detection. Isreal $v$. State Bank of New Orleans (rgog) I24 La. 885,50 So. 783. The depositor is always charged with knowledge of such facts as would be disclosed by a comparison of the checks returned with the stubs in his check book. Critten v. Chenical National Bank (1902) I7I N. Y. 219, 63 N. E. 969. An examination was held to be sufficient where the depositor
} 
made of the materials placed in his hands by the bank. ${ }^{38}$ If, as the courts say, the depositor is under a duty to the bank, it would seem that.

ascertained that the vouchers corresponded with his check stubs, that the balance shown by his check book corresponded with that shown by his pass-book, and then . compared the checks returned with the entries in the pass-book, by himself watching the checks while the dishonest clerk read the entries from the pass-book and concealed discrepancies by omitting to call out the entries of payments of forged checks which he had surreptitiously abstracted. Frank v. Chemical National Bank (I88I) 84 N. Y. 209. A depositor is never required to examine records which are not directly connected with his bank account. National Bank of Commerce v. Tacoma Mill Co. (1910, C. C. A. 9th) 182 Fed. x. Whether a reasonable examination has been made is a question of fact. First National Bank of Richmond v. Richmond Electric Co., supra.

It is generally said that the depositor is not required to look for forged indorsements because he is not supposed to know the payee's signature. National Bank of Commerce v. Fish (1916, Okla.) I69 Pac. r105; Pratt v. Union National Bank (1909) 79 N. J. L. II7, 75 Atl. 313; Los Angeles Investment Co. v. Home Savings Bank of Los Angeles (I9I9) I80 Calif. 60I, I82 Pac. 293. But where there are circumstances sufficient to excite the suspicions of a reasonably prudent man as to the genuineness of indorsements, the depositor must make inquiry. Wind $v$. Fifth National Bank (1889) 39 Mo. App. 72; Atlanta National Bank v. Burke (I888) 8I Ga. 597, 7 S. E. 738; Osborn v. Corn Exchange National Bank (I920) 218 IIl. App. 28. Where a corporation issued its checks for the purpose of making loans, it had notice that the payee's indorsements were forged where the blank indorsement of its treasurer appeared immediately underneath that of the payee. Pannonia Building \& Loan Association v. West Side Trust Co. (19I9) 93 N. J. L. 377, 108 Atl. 240 . See Notes (Ig20) 5 Corn. L. Quart. I60. But the drawer must tender such a check to the drawee bank before he can recover the amount paid on it. See Keamey v. Metropolitan Trust Co. (Ig05) Iro App. Div. 236,97 N. Y. Supp. 274, aff'd I86 N. Y. 6II, 79 N. E. Iro8.

A great diversity of view exists as to what constitutes a performance of the depositor's duty in the examination of his statement and vouchers when he does not make the examination personally. It seems sufficient if made by a faithful and competent employee. Shipman v. Bank of the State (I89I) I26 N. Y. 3I8, 27 N. E. 37I. And all the authorities agree that the depositor is not charged with knowledge of the forgery because of the fact that his clerk, who committed it, had knowledge of it. First National Bank v. Richmond Electric Co. (I907) I06 Va. 347, 56 S. E. I52; Shipman v. Bank of State, supra. But if the examination is entrusted to the dishonest employee, who forged the checks, as is very often the case, the following rules as to its sufficiency have been applied: (I) By entrusting the examination to the dishonest employee, the depositor is charged with the employee's antecedent knowledge. First National Bank v. Richmond Electric Co., supra. (2) Such an examination is in legal effect no examination at all. August v. Fourth National Bank (I888, Sup. Ct.) 48 Hun, 620, I N. Y. Supp. I39. (3) The depositor fulfills his duty by entrusting the examination to an employee reasonably believed to be honest and competent. Kemeth Investment Co. v. National Bank of the Republic (I903) ro3 Mo. App. 6I3, 77 S. W. 1002. (4) The depositor is charged with such knowledge as a reasonable examination would have disclosed to a competent and honest employee. Dana $v$. National Bank of the Republic, supra note 32 . (5) If a reasonable supervision, by the depositor, of the dishonest employee's examination would have disclosed the forgeries, the depositor is charged with knowledge. Leather Mamufacturers' Bank v. Morgan, supra. The fourth test seems to be most generally used.

${ }^{39} \mathrm{~A}$ depositor who left his pass-book to be balanced and neglected for two 
the ordinary rule that one must compensate another for such injury as proximately results from a failure to perform his duty would be entirely adequate. But, say the courts, the depositor, by failing to object when he knows or ought to know of the forgery, thereby represents that such checks are genuine, and when the bank relies upon such representation, the depositor's mouth is closed to deny that they are genuine. They make the consequence the same as if the depositor had in some way represented that the check was genuine, thereby causing the bank to pay. It must, however, be borne in mind that it was no act or representation of the depositor that caused the bank to pay the check. In an English case, so great was the importance attached to this fact that the depositor's neglect was said not to be the "effective cause" of the bank's loss. Mr. Justice Channell said :39

"The authorities are rather against the contention that there is a duty on the part of the depositor to examine his pass-book, but the point is not very important because even if there was a duty the particular loss by honoring the first check was not caused by the nonperformance of that duty."

This reasoning, however, is not convincing because it proceeds from an erroneous conception of the depositor's duty. That duty has never been held to come into existence until the depositor is charged with knowledge that his name has been forged, and this must necessarily be subsequent to payment. Moreover, when it exists, it is not simply to examine the pass-book and cancelled checks. It includes also the giving of notice. If it did not include this, it would be worthless to the bank for whose benefit alone it is imposed, and the bank could never recover more than nominal damages, because a breach could never in fact cause injury. Furthermore, the question whether the depositor's neglect of duty has caused injury to the bank is not referred and limited to the moment at which the check was paid. Inquiry must be made as to whether the bank would have been benefited by prompt notice. To the extent to which it is made less able by the delay or inaction to get other dollars to replace those paid to the forger there is injury and it is "effectively caused" by the depositor's failure to perform his duty.

Those courts in this country which apply the doctrine of estoppel reach the other extreme. Assuming the depositor not to have given prompt notice, when he has actual or constructive knowledge of for-

months to call for it was held not charged with notice that forged checks had been debited to his account. It is necessary that the pass-book and vouchers be actually placed in his hands. McCarty $v$. First National Bank of Birmingham (I920) 204 Ala. 424,85 So. 754.

Walker v. Manchester \& Liverpool District Banking Co. (1913, K. B.) 29 T. I. R. 492, 493. 
geries, the bank has a complete defence against his claim to the extent to which it has paid such checks, provided that the bank sustains any injury as a result. A few of such courts have held that mere delay in proceeding against the forger is sufficient injury, ${ }^{40}$ but according to the view of the great majority, it must appear that some advantage would have resulted from such a proceeding. ${ }^{41}$ They all agree that it is not necessary that the bank show a loss resulting from the depositor's neglect equal in amount to the forged checks paid.

This view, unless either the depositor has actual knowledge or the loss to the bank is the amount of the forged checks, satisfies the requirements of justice no more than does that of implied ratification. The depositor made no representation as to the validity of the checks; and when the bank paid them, intending thereby to decrease its indebtedness, it knew that this result could be accomplished only by the exercise of its power and that it must decide for itself whether such a power existed. But the bank is under a duty to pay if the check is valid and its refusal to do so may make it liable to an action for damages. The bank's position is therefore a difficult one and its honest attempt to perform its duty often exposes it to considerable risk of loss. But for this the bank is compensated, because it becomes the owner of the money deposited and, as such, enjoys its use. If, therefore, the depositor does nothing to mislead it when it pays a forged check, it seems but fair that the bank and not the depositor should have to get its money from the forger or lose it. But the depositor is generally the only one who can know positively whether his signature has been forged and when the bank sends to him his statement and cancelled checks, requesting to be informed if forged cherks are charged to him, it is entirely reasonable to require the depositor to act in order that the bank may thereby be enabled to retrieve the loss incident to innocent error. ${ }^{42}$ If prompt

${ }^{40}$ Leather Manufacturers' Bank v. Morgan (1885) II7 U. S. 96, 6 Sup. Ct. 657 ; Myers v. Southwestern National Bank (I899) I93 Pa. I, 44 Atl. 280; McNeeley Co. v. Bank of North America (I908) 221 Pa. 588, 70 At1. 89r. In Connors v. Old Forge Discount \& Deposit Bank (rgr4) $245 \mathrm{~Pa}$.97, 9r Atl. 2ro, the depositor could not recover the amount of a check when he delayed for forty-three days to give notice of a forged indorsement though it appeared that the forger had already absconded when the plaintiff learned of the forgery.

${ }^{11}$ Any advantage is enough. National Bank of Commerce v. Fish (1916, Okla.) I69 Pac. Iro5; Pratt v. Union National Bank (1909) 79 N. J. L. II7, 75 At1. 313; Janin v. London \& San Francisco Bank (I89I) 92 Calif. 14, 27 Pac. IIoo; Weinstein v. National Bank of Jefferson (1887) 69 Tex. 38, 6 S. W. I7I; Wind v. Fifth National Bank (1889) 39 Mo. App. 72; Murphy v. Metropolitan National Bank (1906) rgI Mass. 159, 77 N. E. 693; Houseman-Spitzley Corporation v. American State Bank (I9I9) 205 Mich. 268, I7r N. W. 543; Harlem Co-operative Building \& Loan Association v. Mercantile Trust Co. (I895, C. P.) 1o Misc. 680, 3I N. Y. Supp. 790.

${ }^{4}$ In some states statutes have been passed providing that "no bank shall be liable to a depositor for the payment by it of a forged or raised check, unless 
notice is given and yet the bank is unable to retrieve its loss, no court holds that the bank has a defence to any extent, because the depositor has been diligent and it was not his duty to prevent loss at all events. If prompt notice would have been of no avail to the bank, most of these courts hold that the depositor's failure to give notice may not be used as a defence against his claim. ${ }^{43}$ To allow the bank to shift its loss to the depositor under such circumstances would be to penalize inaction when action would have been wholly futile. If, however, the bank could have retrieved a part of its loss at the time when notice should have been given, but is unable to collect anything when the forgery is finally discovered, or, if the bank could have recovered completely at the time when notice-should have been given, but is able to collect only a part when it is finally informed of the forgery, these courts hold that the bank has a defence against the depositor's entire claim notwithstanding the fact that prompt action by the depositor could not possibly have resulted in more than a partial replacement of the money paid to the forger by the bank. A duty to prevent such loss as can be prevented only by prompt notice seems to be the utmost that should be required of the depositor, and he should have to pay, or the bank should be allowed an offset against his claim in only such an amount as will compensate the bank for the damage which it would ultimately sustain because of his neglect. But if the orthodox application of the doctrine of estoppel is made, such a result cannot possibly be reached where the injury to the bank is not the exact amount of the forged checks paid. The depositor is entirely estopped or not at all; the bank has a complete defence or none at all. It cannot be denied that the existence of a duty is not vital to an estoppel and that the courts generally find it unnecessary to apply that doctrine where there is a duty. If we say in defence of the courts that apply this principle that they do not mean "duty" when they say it, we have the rather strange result that, where one has no duty to act, his inaction may subject him to greater financial loss than it would if he were under a duty to act.

within one year after the return to the depositor of the voucher of such payment such depositor shall notify such bank that the check so paid was forged or raised. See Pratt v. Union National Bank (I909) 79 N. J. L. Ir7, 75 Atl. 313; Shattuck v. Guardian Trust Co. (19I2) 208 N. Y. 200, 97 N. E. 517. In one state the notice must be given within sixty days. See Denbigh v. First National Bank (I9I8) I02 Wash. 546, I74 Pac. 475. Similar statutes have been enacted in California, Iowa, Kansas, Louisiana, Maine, Massachusetts, Michigan, Minnesota, Ohio, Oregon, Rhode Island, South Dakota, and Wisconsin. Sound commercial policy may require that the depositor give notice at all events when his signature is forged or when the alteration is upon the face of the instrument, but it is questionable whether such a statute should be construed to require notice, under all circumstances, of forged indorsements. See Notes (Ig20) 5 CORN. L. QUart. I60, I64.

${ }^{43}$ See supra note 4I. Contra, authorities cited supra note 40. 
But those same courts that appear to be most confident that the application of the doctrine of estoppel conducts them to a just result have found it necessary rather arbitrarily to limit it. In Leather Manufacturer's Bank v. Morgan, ${ }^{44}$ Mr. Justice Harlan said:

"Of course, if the defendant's officers, before paying the altered checks, could by proper care and skill have detected the forgeries, then it could not receive a credit for the amount of those checks, even if the depositor omitted all examination of his account."45

If there is any reason for this limitation, it must be that the depositor's silence is no representation that the checks paid were genuine; for, if it is, the bank may rely upon it. 'The only apparent reason for saying that silence is no representation is that, under such circumstances, the bank cannot expect the depositor to object when he discovers the forgery. ${ }^{46}$ If such repudiation could reasonably be expected, silence would furnish every reason given by these courts for applying the doctrine if the bank is thereby misled.

In the inquiry as to whether there may be such reasonable expectation, it must be borne in mind that only the depositor can positively know that a check is forged and also that payment, even negligently, of a genuine check decreases the bank's indebtedness. Nor must it be forgotten that silence is a tacit representation, because, under the circumstances, the ordinary person would speak. Furthermore, banks

4 (1885) II7 U. S. 96, II2, 6 Sup. Ct. $657,663$.

${ }^{45}$ If the doctrine of estoppel must be applied to a situation to which it is inapplicable, the limitation here suggested, though from a practical viewpoint it cannot be justified, will serve to decrease injustice to the extent to which it withdraws from the operation of the doctrine cases in which the loss caused by the depositor's neglect is not the amount of the forged checks paid. The limitation suggested is noticed here because it will be relevant later in determining whether

the depositor's silence is a representation that checks paid were genuine upon which the bank can rely in the payment of subsequent checks similarly forged. For this purpose the writer believes that good faith in paying the check is the correct test.

${ }^{36}$ Where the plaintiffs delivered to the defendant a power of attorney, authorizing their clerk to settle their account and draw on it within certain limits, and the defendant paid a number of checks drawn by the clerk in excess of his authority all of which were regularly returned with the monthly statement, it was held that the charges of such checks to plaintiff's account were invalid and that the plaintiff's failure to object to such charges did not estop them, since the power of attorney informed the bank that the clerk would settle the account and it had no reason to believe that the plaintiffs had any knowledge that such checks had been paid. Farrell v. First National Bank (I920, E. D. Pa.) 263 Fed. 778. See Manufacturers' National Bank $v$. Barnes (1872) 65 Ill. 69. The plaintiff was also allowed to recover where the defendant bank paid a number of checks payable to the order of the plaintiff to the plaintiff's clerk, who had authority to indorse for deposit. National Bank of Commerce v. Tacoma Mill Co. (1910, C. C. A. gth) 182 Fed. I. 
have everything to lose and nothing to gain by paying forged checks and never make payment even where there is only a suspicion as to a check presented for payment. Moreover, the bank must form its opinion as to whether the check is genuine in the hurry of business. The depositor cannot know all the circumstances under which the bank paid and he may not conclude that, because it seems obvious to him that the check was forged, it was obvious also to the bank, that it therefore knowingly paid a forged check, and does not need to be notified. If the depositor is ever to be excused from giving notice, it should be only when it is clear that the bank did not pay in good faith; for it is only in such cases that the bank does not need and ought not to expect notice. So limited, occasion for applying the rule would rarely exist.

If it is argued that this rule places on the depositor the duty of protecting the bank from loss in cases where, though it has acted in good faith, it would have been possible for it to discover facts which would have caused it not to part with its money, it may reasonably be replied that because it is undesirable socially that forgers should ultimately succeed in gathering where they have not sown, in view of his relation to the bank, the depositor must act to prevent it to the extent to which his last clear chance is indispensable.

But unless it can be established that, where damage is suffered, it is not necessarily the amount of the forged checks paid, it is clear that the depositor should be denied any recovery and the question as to whether it should be denied on the ground of ratification, adoption, estoppel, or neglect of duty is, at most, of mere academic interest.

Any one of the following situations may well exist where forged checks have been paid: (I) at the time when notice should have been given, no part of the bank's claim against the forger was collectible and the same is true when the bank receives notice ${ }^{47}$ (2) the entire claim is collectible when notice should have been given, and it is still collectible

? Of course, if the payment is to a holder in due course, the doctrine of Price v. Neal (I762, K. B.) 3 Burr. r354, enacted in section 62 of the Negotiable Instruments Laws, prevents'recovery by the bank. Brannon, The Negotiable Instruments Law (1919, 3d ed.) 225. The Supreme Court of Pennsylvania recently refused a recovery to a drawee bank where it had paid a series of twelve forged checks. According to the view of most courts, it was a plain case for the application of Section 62 of the N. I. L. The recovery was denied, however, as to the first ten of the checks, on the ground that the plaintiff's notice, though it was given immediately after the depositor's repudiation of the checks, was too late, and, as to the last two, on the ground that, though notice was prompt enough, payment of the other checks estopped the plaintiff to deny that they were genuine. Union National Bank v. Farmers' \& Mechanics' Bank (I92I) 27I Pa. I07, II4 Atl. 506. Payment of a check is not an acceptance within the meaning of section 62 of the Negotiable Instruments Law, as interpreted by the Pennsylvania courts, and the statute of 1849 (Pub. Laws, 426; Pa. Sts. 1920, sec. I60II), evidently passed for the purpose of repudiating the doctrine of Price $v$. Neal, is still operative. See (Ig2r) 30 Y ALE LAw Journal, 296. 
when notice is received; (3) it was all collectible when notice should have been given and no part is collectible when notice is received; (4) the entire claim was collectible when notice should have been given and a part is still collectible when the bank receives notice; (5) only a part of the claim was collectible when notice should have been given and no part is collectible when notice is received. Those courts that apply the doctrine of estoppel recognize the injustice of denying the depositor a recovery in the first situation because no causal connection exists between the depositor's inaction and the inescapable loss. ${ }^{48}$ In class two the bank has not sustained any loss and those same courts have not thought the depositor's inaction a reason for shifting to him the burden of collecting from the forger. ${ }^{49}$ In the third class every American court, irrespective of the principle that it applies, is conducted to the conclusion that the depositor cannot recover any part of his claim because his inaction has caused loss to that extent. If every case not falling within the first and second classes fell within the third, the result reached by the application of the doctrine of estoppel would be unobjectionable; but those courts that apply it are forced to the same conclusion in classes four and five as in class three. This may be because they believe that such cases as are illustrated by the last two classes do not arise or, if they do arise, that justice requires the same result as is required in class three. The view has already been suggested that the latter conclusion is wrong, but it is well to notice that in class four the bank can still collect a part of its claim. The depositor should lose to the extent to which the bank is unable to collect when it receives notice of the forgery, because to that extent his neglect has caused the loss, as in class three; but there is no more reason for placing upon the depositor the burden of collecting the remainder of the claim than in class two. In the fifth case the depositor should lose only that part of the claim that was collectible when he should have given notice. This much of the loss has resulted from his neglect and to this extent he should have to pay or, what is the same thing, the bank should have a defence. But the remainder of the loss could never have been prevented by the depositor and the reasons of class one apply. That injury is not necessarily caused by the depositor's inaction is recognized by these courts in deciding cases falling within classes one and two.50

National Bank of Commerce v. Fish (1916, Okla.) I69 Pac. I105.

* See cases cited in supra note $4 \mathrm{I}$.

${ }^{50}$ This was expressly recognized in the following cases where the signature of the drawer was forged or the check altered. Weinstein v. National Bank of Jefferson (I887) 69 Tex. 38, 6 S. W. 171; Wind v. Fifth National Bank (I889) 39 Mo. App. 72; Critten v. Chemical National Bank (1902) I7I N. Y. 219, 229, 63 N. E. 969, 972. Where the depositor knows or ought to know that an indorsement is forged, his failure to give notice to the bank has the same effect as a failure to give notice that his signature is forged. In the following cases it was expressly recognized that the drawee bank can sustain no injury where it pays 
That, if there is injury, it is not necessarily the amount of the forged checks is obvious from the nature of things. When such is nor the extent of the injury, these courts' own reasons in classes one and two show the injustice of giving the bank a complete defence and demonstrate the justness of the result reached under the minority view, first announced by the Supreme Court of Alabama, that the depositor is under a duty in the strict sense. The application of this theory can result in no injustice. The other theories inevitably work injustice where the depositor has not actual notice of the forgeries and where the ultimate loss to the bank would not be the amount of the forged checks paid.

\section{II}

It is generally agreed that payment of forged checks, after the depositor is charged with notice that similar checks have been paid, is a defence pro tanto against the depositor's claim..$^{51}$ His silence, under such circumstances, is said to be a tacit representation that such former checks were drawn by him, or by his authority, in the form in which they were presented for payment. Of course the depositor makes no representation in fact, because generally he does not know that such checks exist. But, because such payments were reasonably made by the bank, it is thought that its indebtedness should be to this extent reduced, and the fiction of a representation is indulged in by the courts in order to justify this result by the application of a well recognized principle of law. If the depositor's silence as to former forged checks is tantamount to an express representation that the circumstances under which those checks were drawn were such that it exercised a power when it paid them, the same power should exist when subsequent checks are presented which appear to have been likewise drawn, and payment of such checks, without more, should decrease the bank's indebtedness. One court, however among those that are so ready to apply the doctrine of estoppel 'to such part of the depositor's claim as the bank claims to have extinguished by payment of the forged checks in class one, has held that the depositor is not estopped unless the bank shows special injury, e. g., that it has been induced to forbear to take steps which it might otherwise have taken. ${ }^{52}$ Payment in

the check to a holder who is solvent. Harlem Coöperative Building \& Loan Association v. Mercantile Trust Co. (1895, C. P.) Io Misc. 680, 3 I N. Y. Supp. 790 ; Critten v. Chemical National Bank, supra; National Bank of Commerce v. Fish (1916, Okla.) I6I Pac. I105; Brixen v. Deseret National Bank (1888) 5 Utah, 504, I8 Pac. 43. Contra, Cunningham v. First National Bank (I907) 219 Pa. 3Io, 68 Atl. 73I.

${ }^{5}$ This is the view of those courts which follow First National Bank of Birmingham v. Allen, siepra note 7, as well as of those which apply the doctrine of estoppel to the first forged checks returned to the depositor, cited supra notes 40 and $4 \mathrm{r}$.

${ }^{52}$ Weinstein v. National Bank of Jefferson, supra note 50. 
reliance upon an express representation would be all that is required to estop the depositor, and there is no reason to require more where the bank acts upon an appearance created by the depositor's inaction.

But the depositor should not be estopped unless an appearance of genuineness for which he is responsible misleads the bank when it pays. In Hardy \& Bros. v. Chesapeake Bank, ${ }^{53}$ the court said:

"If such facts [either actual or constructive knowledge of the forgeries] be found to exist, then it must also be found, in order to work an estoppel, that the appellee acted, in honoring and paying the nine checks in question, in reference to the conduct of the appellants in failing to make known an objection to the account as stated and balanced in the bankbook on the I3th of July, 1873 , and that such omission and neglect of the appellants did in fact mislead the appellee into the error of paying the nine forged checks now in dispute."

This rule is difficult to apply. Whether the bank acted "in reference to" the depositor's conduct or whether his neglect "did in fact mislead" the bank is not always easy to determine. If a forged check is presented for payment, and the bank is unaware that checks like it have been paid and returned, and it makes such investigation as satisfies it that the check is genuine, the language quoted would seem to indicate that the depositor would not be estopped because his tacit representation had not been relied upon; and this may be correct. If notice of the previous forgeries had been given, however, the subsequent checks would in all probability not have been presented, or the bank would have been so much more on its guard that the forgery would have been discovered. But in Walker v. Manchester \& Liverpool District Banking Co., ${ }^{54} \mathrm{Mr}$. Justice Channell said:

"As regards the second and third checks, it is true that if Mr. Walker had found out about the first check he would have got rid of the fraudulent clerk, and the second and third forgeries would not have been committed. But the fact that Mr. Walker did not do so was not in law the cause of the second and third cheques being forged. At most it was a causa sine qua non, but that will not do."

If, when a forged check is presented, the bank makes no such investigation and has no definite recollection that similar checks have been paid and returned, the language above quoted would seem to indicate that the depositor would not be estopped, as the bank could hardly act "in reference to" and be "in fact" misled by it when, at the time of payment, it did not know of such conduct. But if the depositor is estopped only when payment is made with a definite recollection that similar checks have been paid, returned, and are unrepudiated, there would rarely be occasion to apply the doctrine. The. courts' probably

${ }^{83}$ (I879) 5I Md. 562, 589.

${ }^{54}$ (I9I3, K. B.) 29 T. L. R. 492, 493. 
would not and ought not to restrict the application of the doctrine to such narrow limits. In Israel v. State National Bank, ${ }^{55}$ where it was held that the bank had no defence because of payment of forged checks previous to the return of the statement of account, but otherwise as to such checks subsequently paid, the court said:

"Upon the facts of the instant case, plaintiff did not exercise this due diligence. He failed to report to the bank the forgeries which had revealed themselves to him by the return of his checks on November 2Ist. He cannot recover therefore the amounts which were subsequently paid. Had he made the report, the bank would have been put on its guard."

This seems to be a better statement of the causal relation required to exist between the depositor's conduct and the bank's payment and would doubtless be more generally approved. If so, it would be unnecessary, as seems to be required by the Maryland court, for the bank, in order to make out a prima facie defence of estoppel, to introduce evidence to prove any facts other than previous payment and return of similar checks which had not been repudiated at the time when the checks in question were paid. These facts in themselves would tend to prove that the bank was not put "on its guard" and that payment was the consequence. ${ }^{36}$ If the depositor repels this presumption by showing, for example, that the bank made an independent investigation which caused it to pay, the bank should then have to introduce enough other evidence to prove the facts alleged as a defence, namely, that the depositor's inaction caused it to pay.

Attention has already been directed to Mr. Justice Harlan's dictum ${ }^{57}$ that the bank must show itself free from negligence in paying and the suggestion ventured that payment in good faith is all that should be required. This dictum, so frequently repeated by the courts, was applied in at least one case where the question related to the payment of checks after the depositor was charged with notice of the previous forgeries, and attention was very insufficiently directed to the changed appearance of genuineness which such checks had as a result of the depositor's failure to repudiate the previous forgeries. ${ }^{58}$ If a check should be paid by the bank when there is some slight doubt as to its genuineness, it is clear that a similar check may be later paid with absolute confidence that it is genuine, when the bank has reason to believe

${ }^{55}$ (1909) I24 La. $885,887,50$ So. $783,784$.

${ }^{\infty}$ See Morgan v. United States Mortgage \& Trust Co. (19r3) 208 N. Y. 218, Ior N. E. 871 ; First National Bank of Birmingham v. Allen (1893) I00 Ala. 476, $\mathrm{I}_{4}$ So. 335; Neal v. First National Bank (rgor) 26 Ind. App. 503, 60 N. E. 164; DeFeriet v. Bank of America (187I) 23 La. Ann. 310; National Bank of Commerce v. Tacoma Mill Co. (I9Io) I82 Fed. I.

"See supra note 44.

${ }^{3}$ National Dredging Co. v. Farmers'Bank (1908, Del.) 6 Pen. 580, 69 Atl. 607. 
that the depositor knows that the first check was paid and would object to it if it was not genuine.

There was also a very interesting application of this rule in Critten v. Chemical National Bank, ${ }^{59}$ where a depositor sought to recover the amount of twenty-four forged checks which had been charged to his account. The bank was held not entitled to credit for the first two forgeries which were paid by it before the account was balanced and returned nor for the sixth and subsequent checks; otherwise as to the third, fourth, and fifth. The court said:

"The sixth in sequence of these forgeries was a check of June 2oth, r898, for $\$ 12.49$, altered to the sum of $\$$ II2.49, with the name of the payee erased and "Cash" written in place thereof. The teller of the defendant, who paid the check and was a witness on its behalf, testified that the check showed on its face that the word "Cash" had been written in place of the payee's name over an erasure; that the number of dollars was also written over an erasure; that he did not like the appearance of the check and that it was in such a mutilated condition when it was presented to him that, before paying it, he required Davis to indorse upon the check a receipt for its amount. That the defendant was grossly negligent in paying the check and has only itself to thank for that loss is apparent. But the effect of that negligence did not cease with the payment of the check. The referee might well have found that, had payment of the check been refused or had Davis been required to obtain the indorsement or guaranty of the plaintiffs as to its correctness, the forgeries of Davis would have been exposed and their repetition would not have occurred. That Davis was able to successfully continue from this time to his arrest a series of forgeries is as fairly attributable to the folly of the bank in paying to a clerk a check of his employers which had plainly been altered without making inquiry as to the reason or authority for the alteration, as it was to any carelessness of the plaintiffs in failing to detect the alteration when the checks were returned to them from the bank."

To summarize in conclusion, the bank should have a defence against the depositor's claim to the extent to which it has paid checks in class II, because the payment of such checks has been induced by the depositor's silence. If he has actual knowledge that forged checks in class I have been paid and charged to his account, the bank should likewise have a defence because of such payment, unless the depositor promptly repudiated them. This should be so whether the bank can recover from the forger or not. Ratification seems the sounder basis for this conclusion, since the fair interpretation of silence under such circumstances is that the depositor assents to the charge; and, if he does, it has been seen that sound policy requires that the legal effect should be the same as if he had actually ordered payment. ${ }^{.0}$ The really difficult problem

(I902) I7I N. Y. 219, 231, 63 N. E. 969, 973. See also National Dredging Co. v. Farmers' Bank, supra note 58 .

${ }^{60}$ This also seems to be the proper ground upon which to support Annett $v$. 
relates to the remainder of the checks in class $I$, where the depositor has no actual knowledge of the forgeries and where the extent of the bank's ultimate injury, attributable to the depositor's neglect, is not the same as the amount of the forged checks paid. In such a case, aside from the injustice of the result, the objection that one cannot ratify what he does not know of seems conclusive against the ratification theory. But the depositor's failure to pursue the course of the reasonably diligent business man, when it would have resulted in timely discovery and repudiation of the forgeries to the bank's benefit, must be condemned. The original loss, however, by universal consent, as between the depositor and the bank, falls upon the latter and justice requires that it remain there, unless it appears that it could have been prevented by due diligence on the part of the depositor and unless it also appears that his co-operation was indispensable. Because the estoppel theory does not permit of the shifting to the depositor of loss to such extent, as seems so clearly required by justice, it should be rejected for the duty theory under which this result will in every case be reached.

Chase National Bank (192I) I96 App. Div. 632, I88 N. Y. Supp. 7, where it was held that the payee of a check could not recover of the drawee bank, when the latter had paid the check on the former's forged indorsement and the payee had delayed in notifying the drawee for sixty days after he know his indorsement had been forged, having endeavored in the meantime to collect from the forger. 